\title{
Evaluating the Effectiveness of the Ethnic Relations Course using the CIPP Model: A Performance at the Sultan Idris Education
}

\author{
Siti Noranizahhafizah Boyman
}

\begin{abstract}
The aim of this article was to evaluate the effectiveness of the Ethnic Relations Course in inculcating unity among students at the Sultan Idris Education University (UPSI). This was because the purpose of the course was to foster unity by forming a positive attitude and mind-set among the students. This study used the CIPP (Context, Input, Process, and Product) program evaluation model introduced by Stufflebeam (1967). Surveys and interviews were used to achieve all the objectives of this study. The data used were more detailed as they covered empirical and non-empirical aspects of the field of study. However, this article focused only on the learning outcomes of the Ethnic Relations Course (Product), namely, the level of unity among the students and how it is related to the demographic factors. Five findings were made in this study. Firstly, the results of the analysis revealed that the course had a positive impact on the level of unity among the students, where 99.5 percent of the respondents were able to respect their friends of other races. Secondly, 98.8 percent of the students were willing to help their friends of other races when they were in difficulties. Thirdly, 98.3 percent of the students were tolerant of each other, that is, they could sit together with those from other ethnic groups in the lecture room. Fourthly, 98 percent of them were proud of the ethnic diversity in Malaysia. Finally, the findings showed that demographic factors such as gender, ethnicity, religion and place of residence did not affect the level of unity among the students. The results of this study suggest that the students at the university have responded well to the Ethnic Relations Course and to unity. Hence, with these findings, this study dismisses the allegation that the students at the university do not mix with those of other races. The unity among the students at this university is at a good and satisfactory level.
\end{abstract}

Keywords: (ethnic relations; CIPP Model; effectiveness; unity; UPSI; students)

\section{INTRODUCTION}

Before Malaya gained independence, the population of the country was already comprised of various ethnic groups as a result of the policies of the colonial government. At that time, their lives were separate from the matters concerning education, economic power, settlements and politics. However, after independence, the communities made greater efforts to live together.
Optimistic advancements were made with regard to ethnic relations, as can be seen in Table 1, which shows the development of the social paradigm in Malaysia.

Table. 1 Development of Ethnic Relations

\begin{tabular}{|l|l|}
\hline Era of Change & Paradigm Shift \\
\hline $1950 \mathrm{~s}$ & Ethnic Classifications \\
\hline $1960 \mathrm{~s}$ & Cultural Enrichment \\
\hline $1970 \mathrm{~s}$ & Change in Social Classes \\
\hline $1980 \mathrm{~s}$ & $\begin{array}{l}\text { Identification } \\
\text { Composition }\end{array}$ \\
\hline $2000 \mathrm{~s}$ & $\begin{array}{l}\text { Efforts at Social } \\
\text { Integration }\end{array}$ \\
\hline $2010 \mathrm{~s}$ & \begin{tabular}{l} 
Social \\
\hline
\end{tabular}
\end{tabular}

Source: Shamsul Amri, 2012.

This stability can be considered to be fragile if the people do not really adhere to religious practices and are influenced by external elements. It can also be said that it is the strong primordial bonds plus the sense of belonging that runs deep within the ethnic groups that ultimately gives rise to racial sentiments.

Therefore, various efforts have been made by the government to maintain national unity such as the creation of various policies, programs, and government bodies to manage unity in Malaysia. In addition, the government is also fostering unity in education. One such effort in education is the introduction of the Ethnic Relations Course at public universities. The goal of this course is to foster unity by forming a positive attitude and mind-set among students in order to erode and eliminate racism through an effective education. This is important because students are the future leaders and hope of the country to steer the progress and well-being of Malaysia in a better direction. Therefore, this study was conducted to evaluate the level of unity among students with a focus on the Sultan Idris Education University (UPSI). Why UPSI? UPSI was selected because it is an important public university in the history of national education.

Revised Manuscript Received on June 22, 2019.

Siti Noranizahhafizah Boyman, Dept. of Social Studies \& Citizenship Universiti Pendiddikan Sultan Idris (UPSI) ,35900 Tanjung Malim, Perak, Malaysia 
UPSI was previously known as the Sultan Idris Training College (SITC) (29 November 1922 - 1957), then, the Sultan Idris Teacher Training College (MPSI) (1957 - 1987) and the Sultan Idris Teacher Training Institute (IPSI) (21 February 1987 - April 1997), and finally, UPSI from 1997 until now. Throughout its development, this institution has produced Malay intellectuals who fought and created awareness among the people.

Therefore, this study is important for evaluating the effectiveness of the Ethnic Relations Course among UPSI students given the great history of UPSI and the objective of the course itself. This is because UPSI is a leading university, and it will produce outstanding teachers and leaders of the future.

\section{PROBLEM STATEMENT \& OBJECTIVES}

Malaysia is a country with a multi-ethnic population. After the events of 13 May 1969, unity and cooperation among Malaysians have become the keys to ensuring that peace, strength, stability and development prevail in the country. It is not easy for Malaysia to achieve unity as its population is comprised of people of various races, religions, cultures, economic activities, residential locations and so on. Thus, various efforts have been made by the government to foster unity and integration. One such formal way is through education. This is because education can play an effective role in ensuring the peace of a multi-ethnic nation. Education can also help to create unity and understanding among the races.

In 2005, the Ethnic Relations Course was introduced into public universities by the government in its effort to foster unity among the people. Nevertheless, in terms of its implementation, this subject is taught in universities to a large group of up to 120 students or more in each class. In addition, some of the students who are attending the course do not pay much attention to it and are only taking the subject to fulfil their credit hours. What is worse is that there is a perception among the students that this course is very boring and is a waste of time. It was observed that the students still sat with classmates of their own race while in class, when doing group assignments, eating at the university canteen, in the library and also when participating in association activities.

If this persists, the spirit of unity and integration will be further eroded and will impact efforts at maintaining harmony and the realization of Vision 2020. Therefore, the main objective of this research was to focus on the learning outcomes of the Ethnic Relations Course, which is the Product, by evaluating the level of unity among the students and how it is related to the demographic factors.

\section{LITERATURE REVIEW}

\section{Study on Ethnic Relations and Unity}

One of the researchers who conducted studies on this subject was Shamsul Amri Baharuddin (2008). His work was titled, 'Hubungan etnik di Malaysia: mencari dan mengenal kejernihan dalam kekeruhan'. His study was aimed at evaluating the level of unity in the relationships between the races in Malaysia from the time of independence until now. One of the matters that were discussed was the 4A's process (Assimilation, Accommodation, Acculturation and Amalgamation) through which Malaysia achieved a level of unity in ethnic diversity. Meanwhile, in 2009, he carried out a research titled, 'Culture and governance in Malaysia's survival as a nation', in which he analysed the pre-colonial, current and postcolonial aspects of Malay culture and politics.

Next, Patrick et al. (2011) carried out a study titled, 'Ethnic-based digital divide and internet use amongst Malaysian students. His research was aimed at discovering whether there was an ethnic-based digital divide among urban youths in Malaysia. A questionnaire was randomly distributed among 959 students from the two states of Penang and the Federal Territory (Kuala Lumpur). The findings of the study showed that there were significant differences between the races in terms of ownership of a personal computer at home and the type of internet connection. His study showed that there was not only a digital divide based on income, but also on ethnicity.

Meanwhile, Ding Choo Ming (2013), in his working paper, examined the challenges in managing cultural diversity in a multi-ethnic country. This study showed, in a broad sense, that learning to accept and respect differences is the best way for people from different ethnic groups to understand the values, norms and traditions that will influence how they view, think, interact and share the country with one another. He tried to change the perspective of Malaysians to view the differences and ethnic and cultural diversity in Malaysia in a positive light.

Then, Ahmad Tarmizi et al. (2013) examined the perceptions and behaviours with regard to socio-religious tolerance in Peninsular Malaysia. The findings of their study rejected the views of a few who often portray through the mass media that an atmosphere of disharmony prevails in the context of inter-religious relations in Malaysia. Their analysis showed that the majority of the respondents, especially the Hindus and Buddhists, had a positive view of socio-religious tolerance compared to the Christians and Muslims, thereby indicating that Hindus and Buddhists are more open.

On the other hand, Redwan Yasin et al. (2013) proposed in their study that Islamic values should be fostered to unite the various races in Malaysia. They discussed how the implementation of Islamic values can lead to social unity and integration among both Muslims and non-Muslims. It was slightly different from the work of Kartini (2014a), who looked at the role played by political bodies in the approach to a multi-ethnic society. The study also assessed the integrity of a plural society in the context of contemporary Malaysia. Denison (2014) also touched on politics in his study titled, 'National reconciliation and inclusive development in Malaysia: Conversations among civil society members and public intellectuals'. The study analysed the socio-economic and political realities in efforts to formulate a national policy framework.

Published By: 
Another researcher, Ong Puay Liu (2014), focused on education for social integration and emerging issues in Sabah. This study looked at the form of education and schooling that can drive the process of becoming a Malaysian nation. Thus, a discussion was held on a subproject, Social Integration through the Formation of the $1 \mathrm{R}$ Concept in Malaysian Education, or its abbreviation, ' $1 \mathrm{R}+$ $3 r$ '. When this $1 R+3 r$ formula is translated into English, the $1 \mathrm{R}$ refers to Relationship, and the 3r's stand for recognise, respect, and reconcile. The study targeted primary school students (years 5 dan 6) and secondary school students (forms 4, 5 and 6). A total of 40 students from different classes in each school were involved in the survey, and interview sessions. The results of this study showed that there was social integration between the respondents in the study area.

Denison et al. (2014) also focused on education in his study titled, "Hubungan antara kaum dalam sistem pendidikan di Malaysia", which investigated how far the education conducted in schools had succeeded in creating harmony and unity among the races. Twenty national secondary schools, ten in Selangor and ten in the Federal Territory of Kuala Lumpur, were involved in the study. This study took into consideration the conceptual framework of social integration, while the research methodology involved the use of questionnaires for the institutes, visits to the schools for case studies, focus group discussions and roundtable discussions.

Kartini (2014) once again conducted a study to examine the concept and practice of tolerance in the context of modernization and power-sharing in Malaysia. Her study discussed the power-sharing model, the power-sharing factors in play and the evidence of this. As a result, the findings of this study encouraged an alternative understanding, whereby cultural diversity is viewed as an ethical dimension rather than as a social relationship between different ethnic groups.

Finally, Denison, Muhd Ismail \& Helmy (2014) carried out a study titled, "Cabaran kehidupan di kawasan flat bandar: implikasi terhadap penyampaian perkhidmatan", in which nine neighbourhoods in Selangor, Perak, Kuala Lumpur and Penang were identified with the cooperation of the Department of National Unity and Integration. Their approach involved the use of a combination of methods such as surveys, field studies and questionnaires. The study identified four key challenges, namely, infrastructure, social elements, unity and harmony, as well as management and governance issues. The findings clearly showed that these four key challenges prevented areas with urban flats from remaining in a harmonious community environment. Clearly, in future, public planning and the delivery of services in urban areas must be stepped up to address more specifically the issues and problems of all apartment dwellers. The failure of the authorities to do so will further isolate the low-income groups in urban areas from development and an improved quality of life.

Review of Assessment Models for Courses or Programs One of the researchers who did a study on a model for the evaluation of the effectiveness of a course or program was Azizi (1998). In his study, he discussed the use of the CIPP model to evaluate the Living Skills subject in selected secondary schools in Selangor, Negeri Sembilan, Kelantan, Penang, and Johor. This study evaluated all aspects of the Living Skills subject in terms of the CIPP, namely, context, input, process and product. The findings showed that there are some aspects that need to be improved in the teaching and learning of this subject in secondary schools. By using this assessment, researchers can more clearly see what are the shortcomings that are preventing students from mastering a particular course or subject. Obviously, this assessment model is suitable for evaluating subjects in schools and higher education institutions.

Tiwi (2007) did a study on 'Keberkesanan program pendidikan Alam Sekitar Institut Perguruan Batu Lintang' in Kuching, Sarawak. The study focused on the effectiveness of the Environmental Education program from four dimensions, namely, the context, input, process and product (CIPP), in achieving the objectives of this program. A quantitative approach with a survey method was selected for this study. Several variables were presented in each dimension of the CIPP based on the program being studied. According to the findings, the program that had been implemented had succeeded in achieving the expected targets and objectives in all the CIPP dimensions. This was because the implementation of this program was also aimed at applying measures to shape the attitude towards the environment through the Environmental Education program.

The study by Guili Zhang et al. (2011) titled, 'Using the context, input, process, and product evaluation model (CIPP) as a comprehensive framework to guide the planning, implementation, and assessment of servicelearning programs', was used as a framework for evaluating the concepts, designs, and implementation of learning services projects in on-going improvement efforts. The purpose of this study was to explore the basic theory in the CIPP, outline the key components of the CIPP, analyse and discuss the effectiveness of the model in the field of study. This article explained the importance of using this evaluation model in the learning system. If no evaluation is done, then improvements cannot be made to ensure better services. This model played a vital role in this entire article.

In addition, Siti Hajar et al. (2011) conducted a study titled, "Keberkesanan proses pembelajaran menggunakan teknologi sidang video". The aim of the study was to see whether there is a learning process taking place when students attend video conferencing sessions. The study used a questionnaire that was distributed to 226 respondents at the Distance Education Learning Centre, Universiti Sains Malaysia (USM). The Gagne learning process model approach was used as the basis for the research. This approach is comprised of nine phases, namely, motivation, attention, expectation, rewards, recall, perception selection, coding and long-term storage, response/performance, feedback, and the reinforcement and generalization of learning. The findings of this study showed that most of the students agreed that the use of video conferencing technology contributes to the learning process.

Published By:

Blue Eyes Intelligence Engineering 


\section{Evaluating the Effectiveness of the Ethnic Relations Course using the CIPP Model: A Performance at the}

Sultan Idris Education

The motivation phase is the most important phase that drives the effectiveness of the on-going learning process. The researcher also presented several suggestions for improving the effectiveness of the process through the use of this technology.

Next, Karatas \& Fer (2011) did a study titled, 'CIPP evaluation model scale: development, reliability and validity'. This study was conducted to determine the validity and reliability of an evaluation scale developed by users based on the principles of the CIPP evaluation model. They focused on the evaluation of the context for the English curriculum from the Yildiz Technical University. Guided by this model, experts in context evaluation and scale verification were asked 65 questions. The study was carried out on a large group of students from different faculties at the university concerned. The results of the study indicated that the scale of the CIPP evaluation model is valid and is recognised as being highly reliable in the field of education. It is clear that the CIPP evaluation model can be used in various fields to ensure that innovations can be implemented. Kuo Hung Tseng et al. (2010) studied the use of the CIPP model in the engineering curriculum of several universities in Taiwan. The study involved the use of all the dimensions in the CIPP model to evaluate the effectiveness of the implemented curriculum. The findings of this research enabled improvements to be made to ensure that the products from the curriculum are of good quality both at home and abroad.

Then, there was the study by Monchai and Pramote (2013) titled, 'A multiple intelligence-supported web-based collaborative learning model using Stufflebeam's CIPP evaluation model'. Their research investigated multiple intelligences that support online learning using the CIPP model. Their analysis of this model was divided into five stages, namely (i) studying the link between online learning, group learning techniques, multiple intelligences, and the CIPP model from articles, books and so on, (ii) unstructured interviews on early learning, (iii) analysis of multiple intelligences in support of online learning based on the CIPP model for specific specializations, (iv) a model-based questionnaire, and (v) summary of the model. Their findings showed that the support of multiple intelligences was based on the web collaborative learning model using the CIPP evaluation model, the use of a mixed innovation consisting of web-based learning, collaborative learning techniques and the CIPP evaluation model. The results of the study also showed that this model is very important for assessing and reinforcing programs to obtain quality products. In summary, this model can complement the collaborative web learning program to provide students with effective learning, and to produce students who are able to respond to what is taught, and can effectively realise the learning objectives.

Meanwhile, Mohamad Fadzil \& Abdul Jaleel (2013), conducted a study titled, "Menilai keberkesanan Pelaksanaan program diploma perguruan lepas Ijazah Pendidikan Sejarah sekolah rendah di Institut Pendidikan Guru Kampus Pulau Pinang”. The evaluation was carried out in accordance with the CIPP model with a focus on the input, process and product. The study sample comprised 23 DPLI-SR trainee teachers from the November 2011 intake. The findings showed that 87 percent of the trainee teachers agreed that the input from the pro forma was suitable for future history teachers. 65.2 percent of the trainee teachers admitted that the DPLI program boosted their selfconfidence in teaching history, while 61 percent of the trainee teachers were confident that the activities during the course could be applied in the PnP. Meanwhile, the process aspect showed that a large number of trainee teachers obtained excellent results in all history subjects. The findings of the study showed that all the students obtained grade $\mathrm{A}$ in the practicum, while all the trainee teachers were able to master all the courses that were offered and applied in the history PnP in the classroom during the evaluation of the practicum. In conclusion, this study was conducted with the CIPP evaluation model, which was only able to evaluate the aspects of input, process and product. A comprehensive study involving all aspects of the CIPP evaluation model by taking into consideration all the teacher training institutes and diploma programs can be carried out in an effort to evaluate the effectiveness and quality of the courses being conducted.

Finally, Mat Rasid (2014) conducted a study to evaluate the implementation of the Practical Skills Assessment (PEKA) for Science in national schools based on the Context, Input, Process, and Product (CIPP) Evaluation. The study design combined quantitative and qualitative methods. The selection of the study sample was done by a simple random sampling method involving 20 science teachers from 10 national schools through the Hulu Langat district. The findings showed that the evaluation of the context elements, i.e. the relevance of the PEKA curriculum, the teachers' perception of PEKA, the evaluation of PEKA by the teachers, were moderate. The evaluation of the input elements, i.e. the allocation of teaching time and the contents of the PEKA skills in the textbook, were moderate, while the evaluation of the elements of teaching aid materials (BBM) was negative. The results also showed that in the evaluation of the process elements, the teaching emphasis was positive; the strategy, approach, form, technique and teaching activities were at a moderate level; while the use of BBM, the PEKA evaluation method, and the findings of the product evaluation were found to be negative. In conclusion, the use of the CIPP evaluation model showed that there were many weaknesses that had to be corrected in PEKA to improve its implementation in schools.

\section{METHODOLOGY}

This study used a quantitative method to obtain numerical data. A descriptive analysis was used to view the profile of the demographic characteristics of the respondents, the schooling background of the respondents, the level of unity among the respondents and how it is related to the demographic factors. The frequency and percentage of each data category was calculated for a quantitative comparison to be made. 
This study began with a documentary analysis of books, articles, and reports from the Department of National Unity and Integration, reports from the National Unity Consultative Council (MKPN), papers and newspapers. In the next stage, data was collected by means of a survey or questionnaire. The study was conducted at UPSI, Tanjong Malim Perak. The university, which is located in Tanjung Malim, Perak has 2 campuses, namely, the Sultan Azlan Shah campus and the Sultan Abdul Jalil Shah campus. The study population comprised students from Universiti Pendidikan Sultan Idris. The current student population is estimated to be 12,589 (JHEPA, 2015). Based on the sample size determination table by Krejcie and Morgan (1970), a total of 384 respondents would have been adequate.
However, steps were taken to have more respondents so that the information and data obtained would be better and more reliable to enhance this study. As many as 400 respondents were randomly selected for this study, and they came from various backgrounds and with different ideologies to ensure that the data that was obtained was more varied.

\section{FINDINGS \& DISCUSSION}

\section{Background of Respondents}

This section discusses the diversity of the respondents by looking at their backgrounds based on demographic factors such as their gender, age, ethnicity, religion, educational background and area of residence.

Table. 2 Background of Respondents

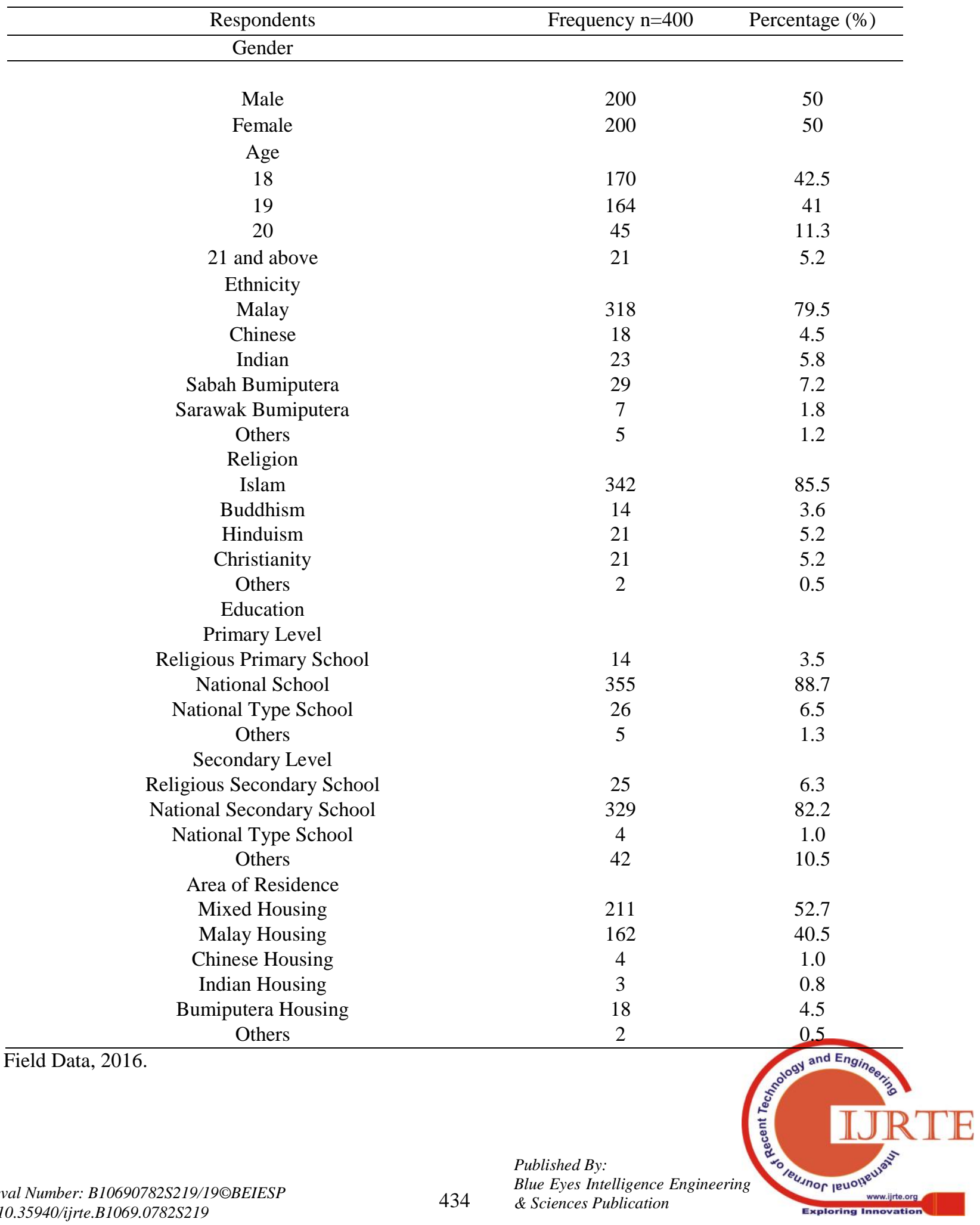




\section{Evaluating the Effectiveness of the Ethnic Relations Course using the CIPP Model: A Performance at the Sultan Idris Education}

Analysis of Learning Outcomes of Ethnic Relations Course (Product) - Level of Unity Among Students

This section analyses and discusses two important aspects in the evaluation of the level of unity among students. The first aspect is focused on the learning outcomes of the Ethnic Relations Course, i.e. the Product, while the second aspect is concerned with how it is related to the demographic factors. The first part will assess the overall level of unity among the students, including the aspects of socialization, communication, relationships of the respondents with friends of different races. The second part will assess the level of unity among students and how it is related to the demographic factors, including gender, ethnicity, religion and area of residence.

The first part refers to Table 3, which shows the evaluation percentage of the level of unity among the students at UPSI. The results of the study showed that the level of unity among the students at UPSI was high based on the following evaluations. An analysis of Table 3 showed that 99.5 percent of the respondents respected their friends of other races and 98.8 percent of them were willing to help their friends of other races if they were in trouble.

Table. 3 Evaluation of Unity

\begin{tabular}{|c|c|c|c|c|}
\hline \multirow[t]{2}{*}{ Item } & \multicolumn{2}{|c|}{ Yes } & \multicolumn{2}{|c|}{ No } \\
\hline & Frequency & $\begin{array}{l}\text { Percentage } \\
(\%)\end{array}$ & $\begin{array}{l}\text { Frequenc } \\
\mathrm{y}\end{array}$ & $\begin{array}{l}\text { Percentage } \\
(\%)\end{array}$ \\
\hline Appreciate the advantages of diversity & 375 & 94.0 & 25 & 6.0 \\
\hline Proud of the diversity & 392 & 98.0 & 8 & 2.0 \\
\hline Support the efforts of the government & 387 & 96.8 & 13 & 3.3 \\
\hline Open towards other races & 388 & 97.0 & 12 & 3.0 \\
\hline $\begin{array}{l}\text { Able to accept roommate of a different } \\
\text { race }\end{array}$ & 340 & 85.0 & 60 & 15.0 \\
\hline Able to joke with friends & 373 & 93.3 & 27 & 6.8 \\
\hline $\begin{array}{l}\text { Able to sit at the same table and eat } \\
\text { together }\end{array}$ & 382 & 95.5 & 18 & 4.5 \\
\hline Able to visit sick friends & 344 & 86.0 & 56 & 14.0 \\
\hline Only friends with those of the same race & 58 & 14.5 & 342 & 85.5 \\
\hline Able to give gifts to other friends & 220 & 55.0 & 180 & 45.0 \\
\hline $\begin{array}{l}\text { Able to celebrate at gatherings and } \\
\text { festivals }\end{array}$ & 327 & 81.8 & 73 & 18.2 \\
\hline Able to greet one another on meeting & 386 & 96.5 & 14 & 3.5 \\
\hline Able to work together on assignments & 384 & 96.0 & 16 & 4.0 \\
\hline Able to sit together in the lecture room & 393 & 98.3 & 7 & 1.7 \\
\hline $\begin{array}{l}\text { Able to share opinions during } \\
\text { presentations }\end{array}$ & 367 & 92.0 & 33 & 8.0 \\
\hline Able to share food and drinks & 243 & 60.8 & 157 & 39.3 \\
\hline Able to help friends who are in trouble & 395 & 98.8 & 5 & 1.3 \\
\hline $\begin{array}{l}\text { Choose friends of other races in college } \\
\text { activities }\end{array}$ & 282 & 70.5 & 118 & 29.5 \\
\hline Attending cultural activities & 273 & 68.3 & 127 & 31.8 \\
\hline Able to sit with other races on the bus & 385 & 96.3 & 15 & 3.7 \\
\hline $\begin{array}{l}\text { No problem learning the language of } \\
\text { another race }\end{array}$ & 336 & 84.0 & 64 & 16.0 \\
\hline $\begin{array}{l}\text { Prepared to use the language of another } \\
\text { race }\end{array}$ & 331 & 82.8 & 69 & 17.3 \\
\hline Respect friends of other races & 398 & 99.5 & 2 & 0.5 \\
\hline
\end{tabular}

Source: Field Data, 2016.

In addition, 98.3 percent of the respondents had a tolerant attitude such that they were able to sit together with those of other races in the lecture room, and 98 percent of them were proud of the ethnic diversity in Malaysia. The lecturers also encouraged the students to be in mixed racial groups in the lecture room. It was observed that the students had no problem sitting next to a classmate of a different race because of their openness. This indicated a positive development among the 
students at UPSI. Pure values could be shared with classmates of different ethnicities because the respondents were very aware that they were all equals. It was obvious that when the respondents were able to respect each other, the social and communication aspects worked well without conflict. This was also evident during the celebration of festivals at the university, when all the students did not mind attending an event to share the experience of celebrating or participating in the cultural activities of other races. In fact, the students were excited about spending their time doing something beneficial and useful.

On the whole, four items had low percentages, namely, 70.5 percent of the respondents would choose friends of other races in college activities, while 96.5 percent of them had no problem greeting one another. The second item with a low percentage of 68.3 percent was attending cultural activities. Nevertheless, 81.8 percent of the respondents celebrated gatherings and festivals together.

The third item with a low percentage of 60.8 percent was sharing food and drinks, while 95.5 percent of the respondents had no problem sitting at the same table and eating together. Finally, the lowest percentage of 55 percent went to giving gifts to other friends. However, 86 percent of them would visit sick friends.

Hence, this indicated that the students showed a good response towards ethnic relations. This means that the speculation that university students do not mix with different ethnic groups is merely an assumption.

Analysis of the Learning Outcomes of the Ethnic Relations Course (Product) - The Level of Unity Among Students and how it is Related to the Demographic Factors

The first part above was a comprehensive evaluation of the aspects of socialization, communication, and the relationship between the respondents and their friends of different races. This second part assesses the level of unity among the students and how it is related to the demographic factors of gender, ethnicity, religion and area of residence.

Among the items that were analysed further to see how they were related to the demographic factors were respect for friends of other races, prepared to help friends of other races who are in trouble, able to sit together with friends of other races in the lecture room, and being proud of the ethnic diversity in Malaysia.

Table. 4 Evaluation of Unity and how it is Related to Gender

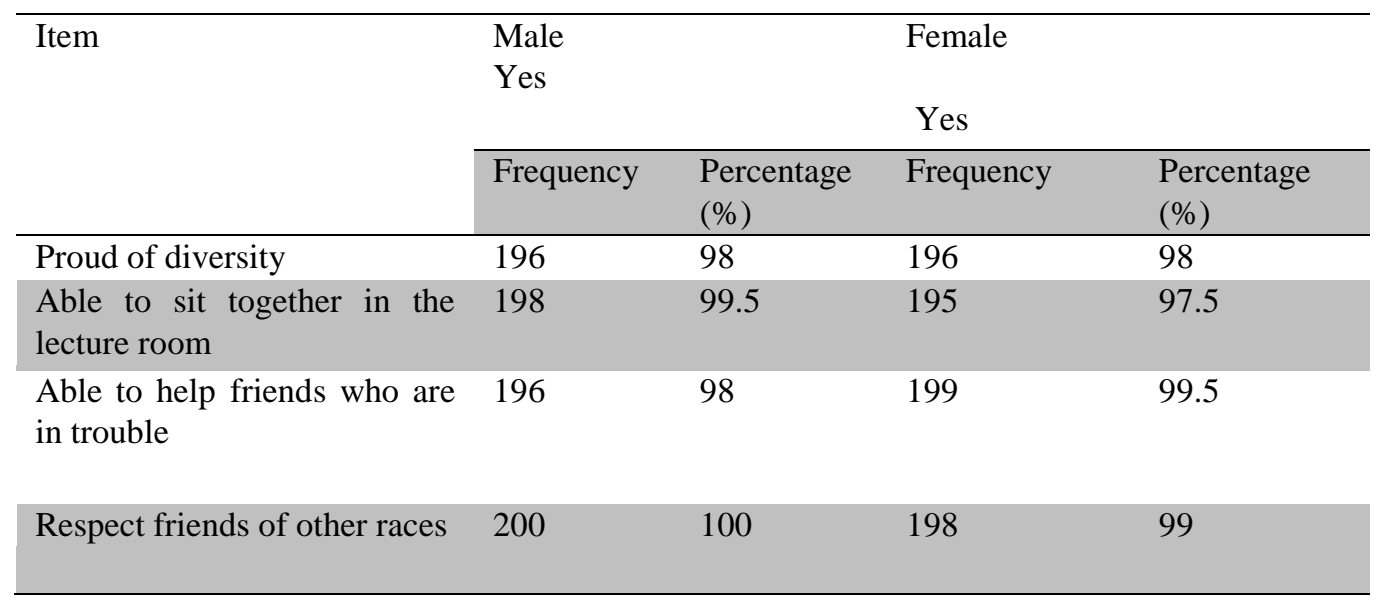

Source: Field Data, 2016.

The first analysis refers to Table 4, which shows the evaluation of unity for four selected items and how it is related to gender. The results of the analysis showed that both genders had a positive attitude towards the four items of unity, scoring percentages of 98 percent and above. This finding showed that the gender of the students was not a significant factor in determining the values of unity. 
Evaluating the Effectiveness of the Ethnic Relations Course using the CIPP Model: A Performance at the Sultan Idris Education

Table. 5 Evaluation of Unity and how it is Related to Ethnicity

\begin{tabular}{|c|c|c|c|c|c|}
\hline \multirow[t]{3}{*}{ Item } & \multicolumn{5}{|c|}{ Ethnicity (Yes) } \\
\hline & Malay & Chinese & Indian & Sabahan & Sarawakian \\
\hline & $\begin{array}{l}\text { Frequenc } \\
\mathrm{y}(\%)\end{array}$ & Frequency (\%) & $\begin{array}{l}\text { Frequenc } \\
\mathrm{y}(\%)\end{array}$ & $\begin{array}{l}\text { Frequency } \\
(\%)\end{array}$ & $\begin{array}{l}\text { Frequency } \\
(\%)\end{array}$ \\
\hline Proud of diversity & $\begin{array}{l}310 \\
(97.5)\end{array}$ & $18(100)$ & $23(100)$ & $29(100)$ & $7(100)$ \\
\hline $\begin{array}{l}\text { Able to sit together in the } \\
\text { lecture room }\end{array}$ & $\begin{array}{l}311 \\
(98.1)\end{array}$ & $18(100)$ & $23(100)$ & $29(100)$ & $7(100)$ \\
\hline $\begin{array}{l}\text { Able to help friends who } \\
\text { are in trouble }\end{array}$ & $\begin{array}{l}313 \\
(98.4)\end{array}$ & $18(100)$ & $23(100)$ & $29(100)$ & $7(100)$ \\
\hline $\begin{array}{l}\text { Respect friends of other } \\
\text { races }\end{array}$ & $\begin{array}{l}316 \\
(99.4)\end{array}$ & $18(100)$ & $23(100)$ & $29(100)$ & $7(100)$ \\
\hline
\end{tabular}

Source: Field Data, 2016.

The next discussion has to do with the evaluation of unity and how it is related to ethnicity. Based on Table 5, the findings of the analysis showed that all five ethnic groups, namely, the Malays, Chinese, Indians, Sabahans and Sarawakians, had a positive attitude towards all the four items of unity with a percentage of 97 percent and above. This finding showed that ethnicity was not a significant factor in determining the values of unity. In addition, this finding also means that the ethnic diversity of the students at the university did not have a negative impact on efforts to foster unity.

Table. 6 Evaluation of Unity and how it is Related to Religion

\begin{tabular}{cccccc}
\hline \multirow{2}{*}{ Item } & \multicolumn{5}{c}{ Religion (Yes) } \\
\cline { 2 - 6 } & Islam & Buddhism & Hinduism & Christianity & Others \\
\cline { 2 - 6 } & $\begin{array}{c}\text { Frequency } \\
(\%)\end{array}$ & $\begin{array}{c}\text { Frequency } \\
(\%)\end{array}$ & $\begin{array}{c}\text { Frequency } \\
(\%)\end{array}$ & $\begin{array}{c}\text { Frequency } \\
(\%)\end{array}$ & $\begin{array}{c}\text { Frequency } \\
(\%)\end{array}$ \\
\cline { 2 - 6 } $\begin{array}{c}\text { Proud of diversity } \\
\text { 334(97.7) }\end{array}$ & $14(100)$ & $21(100)$ & $21(100)$ & $2(100)$ \\
$\begin{array}{c}\text { Able to sit together in } \\
\text { the lecture room }\end{array}$ & $335(98.2)$ & $14(100)$ & $21(100)$ & $21(100)$ & $2(100)$ \\
$\begin{array}{c}\text { Able to help friends } \\
\text { who are in trouble }\end{array}$ & $337(98.5)$ & $14(100)$ & $21(100)$ & $21(100)$ & $2(100)$ \\
$\begin{array}{c}\text { Respect friends of } \\
\text { other races }\end{array}$ & $340(99.4)$ & $14(100)$ & $21(100)$ & $21(100)$ & $2(100)$ \\
\hline
\end{tabular}

Source: Field Data, 2016.

The following analysis refers to Table 6, which shows the evaluation of unity and how it is related to religion. The results of the analysis showed that the respondents from all five religions, namely Islam, Buddhism, Hinduism, Christianity and others, had positive values with regard to all the four items of unity, with a percentage of 97 percent and above. This finding showed that religion was not a significant factor in determining the values of unity. This also means that the religion of a person had no bearing on ethnic relations and unity in the university.

Table. 7 Evaluation of Unity and how it is Related to Area of Residence

\begin{tabular}{|c|c|c|c|c|c|}
\hline \multirow[t]{3}{*}{ Item } & \multicolumn{5}{|c|}{ Housing (Yes) } \\
\hline & Mixed & Melayu & Cina & India & $\begin{array}{c}\text { Bumiputer } \\
\mathrm{a}\end{array}$ \\
\hline & $\begin{array}{c}\text { Frequency } \\
(\%)\end{array}$ & $\begin{array}{c}\text { Frequency } \\
(\%)\end{array}$ & $\begin{array}{c}\text { Frequenc } \\
\text { y }(\%)\end{array}$ & $\begin{array}{c}\text { Frequenc } \\
\mathrm{y}(\%)\end{array}$ & $\begin{array}{c}\text { Frequency } \\
(\%)\end{array}$ \\
\hline Proud of diversity & $210(99.5)$ & $155(95.7)$ & $4(100)$ & $1(100)$ & $18(100)$ \\
\hline $\begin{array}{c}\text { Able to sit together in the lecture } \\
\text { room }\end{array}$ & $207(98.6)$ & $159(98.1)$ & $4(100)$ & $1(100)$ & $18(100)$ \\
\hline $\begin{array}{l}\text { Able to help friends who are in } \\
\text { trouble }\end{array}$ & $210(99.5)$ & $158(97.5)$ & $4(100)$ & $1(100)$ & $18(100)$ \\
\hline Respect friends of other races & $210(99.5)$ & $162(100)$ & $4(100)$ & $1(100)$ & $17(94.4)$ \\
\hline urce: Field Data, 2016 & & & & & \\
\hline
\end{tabular}


Finally, an analysis with regard to the evaluation of unity and how it is related to the area of residence was carried out. Based on Table 7, the results of the analysis showed that 95 percent and above of all the five ethnic groups living in Mixed, Malay, Chinese Indian and Bumiputera housing areas had a positive attitude with regard to all the four items of unity. This finding showed that the area of residence was not a significant factor in determining the values of unity. In addition, this finding also means that the housing areas in which the students were living had no influence over ethnic relations and unity among the students.

\section{CONCLUSION}

From the results of the study that was carried out, it can be summarised that the analysis of the learning outcomes of the Ethnic Relations Course (product), namely, the evaluation of the level of unity among the students, showed that the course had a positive effect, with 99.5 percent of the respondents respecting their friends of other races and 98.8 percent of them being willing to help their friends of other races. In addition, the respondents had a tolerant attitude, where 98.3 percent of them were able to sit together with their friends of other races in the lecture room, and 98 percent of them were proud of the ethnic diversity in Malaysia. This study also found that demographic factors such as gender, ethnicity, religion and place of residence did not influence the evaluation of the level of unity among students. This finding means that the students had responded well to the Ethnic Relations Course. Furthermore, the results of this study served to dismiss the allegation that university students do not mix with those of other races as mere assumption. Among the students at the university there was a good and satisfactory level of unity.

\section{ACKNOWLEDGMENT}

This research was supported by Universiti Pendidikan Sultan Idris as has funded this research through Research Grant University (GPU). We also thank our colleagues from UPSI who provided insight and expertise that greatly assisted the research.

\section{REFERENCES}

1. Ahmad Tarmizi Talib, Sarjit S. Gill \& Nur Ayuni Mohd Isa. (2013). Persepsi dan Tingkahlaku Terhadap Toleransi Sosio Agama di Semenanjung Malaysia. Prosiding Seminar Penyelidikan Siswazah UniSZA, 907-911.

2. Azizi Yahaya (1998). Penggunaan Model KIPP dalam penilaian mata pelajaran Kemahiran Hidup di sekolah-sekolah menengah di Malaysia. Review Malaysian Academic Library Institutional Repository.

3. Guili Zhang, Nancy Zeller, Robin Griffith, Debbie Metcalf, Jennifer Williams, Christine Shea, \& Katherine Misulis. (2011). Using the context, input, process, and product evaluation model (CIPP) as a comprehensive framework to guide the planning, implementation, and assessment of service-learning programs. Journal Of Higher Education Outreach And Engagement, 15(4), 57-70.

4. Denison Jayasoorin, Teo Lee Ken. Mudh Ismail \& Saifful Hassan. (2014). Hubungan antara kaum dalam sistem pendidikan di Malaysia. Kertas Laporan Penyelidikan KITA-UKM, bil 2.

5. Ding Choo Ming. (2013). Some challenges in managing cultural difference in a multi-ethnic country: Malaysia. Prosiding Seminar Antarabangsa Etnik \& Dasar: Refleksi Jati Diri, 30-38.
6. Karatas Hakan \& Fer Seval (2011). CIPP evaluation model scale development, reliability and validity. Procedia Social and Behavioral Sciences, 15, 592-599.

7. Kartini Aboo Talib@ Khalid. (2014b). Moderation and power sharing in Malaysia: accommodating concept and practice. Siri Kertas KITAUKM, bil 33. (September).

8. Krejcie, R.V., \& Morgan, D.W. (1970). Determining sample size for research activities. Educational and Psychological Measurement, 30, 607-610.

9. Mat Rasid Ishak. (2014). Kajian keberkesanan Program Pentaksiran Kerja Amali Sains (PEKA): Satu penilaian di sekolah rendah. Jurnal Pendidikan Malaysia, 39(2), 83-93.

10. Mohd Fadzil Che Amat \& Abdul Jaleel Abdul Hakeem. (2013). Menilai keberkesanan pelaksanaan Program Diploma Perguruan Lepas Ijazah Pendidikan Sejarah Sekolah Rendah di Institut Pendidikan Guru Kampus Pulau Pinang. Seminar Pendidikan Sejarah dan Geografi, Universiti Malaysia Sabah, hlm. 214-225.

11. Monchai Tiantong \& Pramote. (2013). A multiple intelligences supported web-based collaborative learning model using Stufflebeam's CIPP evaluation model. Review International Journal Of Humanities And Social Science, Vol 3, No 7: hlm157-165

12. Ong Puay Liu (edi) (2014). Pendidikan untuk kesepaduan sosial: Isuisu berbangkit untuk Sabah. Kertas Laporan Penyelidikan KITA-UKM, bil 5 (nov).

13. Patrick C-H, Soh Kok Wai, Chew, Chettiar Arumugan, Veeri \& Peng Hwa,Ang.(2011). Ethnic-based digital divide and internet use amongst Malaysian students. Jurnal Akademika, 81(1), 93-100.

14. Redwan Yasin, Mohd Ridhuan Tee Abdullah, Sayuti Ab. Ghani \& Mohd Faizul Azmi. (2013). Pemupukan nilai keislaman dalam perpaduan masyarakat berbilang kaum di Malaysia. Prosiding Seminar Antarabangsa Etnik \& Dasar: Refleksi Jati Diri, 18-24.

15. Siti Hajar Halili, Shukri Sulaiman \& Mohd Razha Abd. Rashid. (2011). Keberkesanan proses pembelajaran menggunakan teknologi sidang video. Review Jurnal Pendidikan Malaysia, 36(1), 55-65.

16. Shamsul Amri Baharuddin. (2008). Hubungan etnik di Malaysia: mencari dan mengekal kejernihan dalam kekeruhan. Siri Kertas KITAUKM, bil 3. (September).

17. Shamsul Amri Baharuddin (2009). Culture and Governance in Malaysia's survival as a nation. Kertas Laporan Penyelidikan KITAUKM, bil 3. (September).

18. Shamsul Amri Baharuddin. (2012). Modul Hubungan Etnik (Ed.2). Bangi: Universiti Kebangsaan Malaysia.

19. Tiwi Kamidin. (2007). Keberkesanan program Pendidikan Alam Sekitar Institut Perguruan Batu Lintang. Seminar Penyelidikan Pendidikan. Institut Perguruan Batu Lintang.

20. Tunku Abdul Rahman. (2007). 13 Mei 1969 sebelum dan selepas. Kuala Lumpur: Utusan Publications \& Distributors. 